\title{
Fabrication and Evaluation of Complimentary Logic Circuits Using Zinc Oxide and Pentacene Thin Film Transistor
}

\author{
Hiroyuki Iechi Member (RICOH Co., LTD. \& ChibaUniversity, iechi@rdc.ricoh.co.jp) \\ Yasuyuki Watanabe Non-member (ChibaUniversity, watabey@faculty.chiba-u. jp) \\ Hiroshi Yamauchi Non-member (ChibaUniversity, yamauchi@office.chiba-u.jp) \\ Kazuhiro Kudo Member (ChibaUniversity, kudo@ faculty.chiba-u.jp)
}

Keywords : zinc oxide, pentacene, thin film transistor, organic transistor, CMOS inverter, charge transfer

Organic field effect transistors (OFETs) based on organic semiconductors are indispensable for fabricating the flexible displays, electronic papers, sensors, and radio frequency identification cards (RFIDs). Much work has been continuously devoted to achieving the high field effect mobility and to understanding the operation mechanism of the OFETs in order to realize the high performance devices. It has been reported in the articles that pentacene FET and crystal-rubren FET show high field-effect mobility of $1.0 \mathrm{~cm}^{2} / \mathrm{Vs}$ and $18 \mathrm{~cm}^{2} / \mathrm{Vs}$, respectively. The main application of OFETs in recent reports is related to pixel switches in active-matrix displays but some reports on other devices such as inverter circuits and logic circuits are very important devices for realizing flexible sheet displays. To realize the complementary circuits and logic circuits using organic materials, we need to have both n-channel and p-channel organic transistors. However, the majority of organic materials show p-type semiconducting properties and we have a little n-type organic material. It is hardly possible to realize n-type transistor having high operation properties. Therefore, we have proposed hybrid complementary metal oxide semiconductor (CMOS) inverters with n-channel zinc oxide $(\mathrm{ZnO})$ transistors as the n-type inorganic material and $\mathrm{p}$-channel organic transistors using pentacene as the p-type organic material.

In this study, we demonstrate the basic characteristics of the CMOS inverters with $\mathrm{ZnO}$ and pentacene transistors. Next, we describe basic charge transfer characteristics of $\mathrm{ZnO}$ thin films.

Figure 1 shows a schematic diagram and measurement circuit of $\mathrm{ZnO}$ and pentacene transistors. A heavily doped p-type Si wafer was used, and the thicknesses of the chemical vapor deposition $\mathrm{SiN}$ and $\mathrm{SiO}_{2}$ double gate dielectric layer are $150 \mathrm{~nm}$ and $400 \mathrm{~nm}$, respectively. The channel length of the pentacene FET is $100 \mu \mathrm{m}$

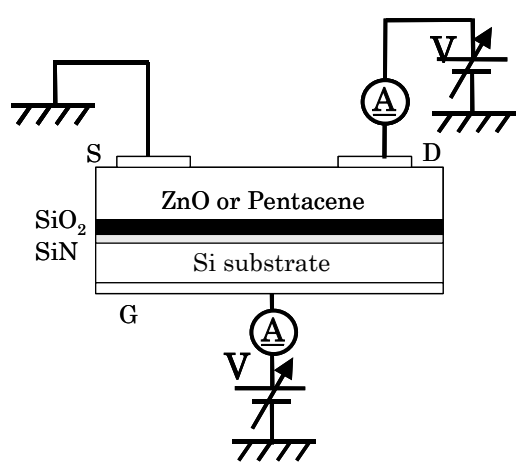

Fig. 1. Schematic diagram and measurement circuit of $\mathrm{ZnO}$ and pentacene transistors and channel width is $30 \mathrm{~mm}$. On the other hand, the channel length of the $\mathrm{ZnO}$ FET is $20 \mu \mathrm{m}$ and channel width is $3 \mathrm{~mm}$. $\mathrm{ZnO}$ thin film transistors show n-type semiconducting properties having field-effect mobility of $2.1 \times 10^{-3} \mathrm{~cm}^{2} / \mathrm{Vs}$. On the other hand, pentacene thin film transistors show p-type semiconducting properties having field-effect mobility of $3.2 \times 10^{-2} \mathrm{~cm}^{2} / \mathrm{Vs}$. Figure 2 shows the voltage transfer characteristics of CMOS inverter using $\mathrm{n}$-channel $\mathrm{ZnO}$ and $\mathrm{p}$-channel pentacene transistors. The complementary inverter exhibited a large voltage gain $\left(\right.$ Gain $\left.=\Delta V_{\text {out }} / \Delta V_{\text {in }}\right)$ of $10-12$. Figure 3 shows a current vs bias voltage plots of $\mathrm{ZnO}$ thin films in order to investigate the electron injection mechanism at the interface between $\mathrm{ZnO}$ thin film and ITO. The results obtained here demonstrate that it is important for the transistor using $\mathrm{ZnO}$ to inject charge from electrode to semiconducting material effectively.

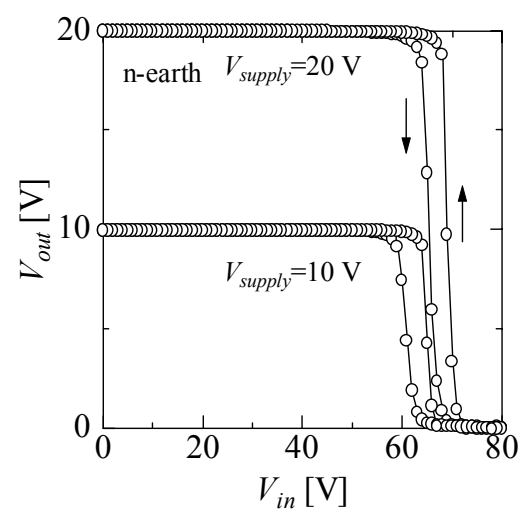

Fig. 2. Voltage transfer characteristics of CMOS inverter employing pentacene and $\mathrm{ZnO}$ transistor

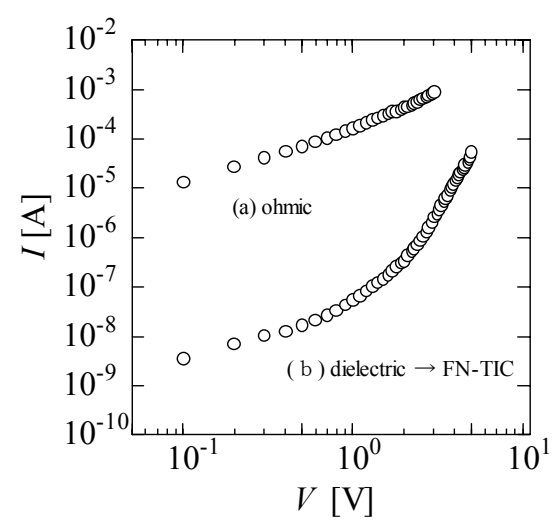

Fig. 3. Current vs bias voltage plots of $\mathrm{ZnO}$ thin films 


\title{
酸化亜鈶とペンタセン薄膜トランジスタを用いた \\ コンプリメンタリー型論理素子の作製と評価
}

\author{
正 員 家地 洋之*,*** 非会員 渡邊 康之** \\ 非会員 山内 博*** 正員 工藤 一浩***
}

\section{Fabrication and Evaluation of Complimentary Logic Circuits Using Zinc Oxide and Pentacene Thin Film Transistor}

Hiroyuki Iechi****, Member, Yasuyuki Watanabe**, Non־member, Hiroshi Yamauchi***, Non־member, Kazuhiro Kudo***, Member

We fabricated hybrid complementary inverters with $\mathrm{n}$-channel zinc oxide $(\mathrm{ZnO})$ transistors as the $\mathrm{n}$-type inorganic material and p-channel organic transistors using pentacene as the p-type organic material. The complementary inverter exhibited a large voltage gain of $10-12$ and a cut off frequency of $0.5 \mathrm{kHz}$. ZnO thin film transistors show $n$-type semiconducting properties having field effect mobility of $2.1 \times 10^{-3} \mathrm{~cm}^{2} / \mathrm{Vs}$. On the other hand, pentacene thin film transistors show p-type semiconducting properties having field effect mobility of $3.2 \times$ $10^{-2} \mathrm{~cm}^{2} / \mathrm{Vs}$. We describe basic charge transfer characteristics of $\mathrm{ZnO}$ thin films. The results obtained here demonstrate that it is important for the transistor using $\mathrm{ZnO}$ to be injected charge from electrode to semiconducting material effectively.

キーワード : 酸化亜鈶, ペンタセン, 薄膜トランジスタ, 有機トランジスタ, CMOS インバーター, 電荷輸送

Keywords : zinc oxide, pentacene, thin film transistor, organic transistor, CMOS inverter, charge transfer

\section{1. はじめに}

有機トランジスタは，フレキシブルディスプレイ，電子 ペーパー(1)，センサー(2)(3)，RFID（Radio Frequency Identification）カード(4)などを実現できる可能性を秘めて いることから注目されている。これらを実現するために， 高性能有機トランジスタが必要である。これまでに，ポリ イミド上のペンタセントランジスタの移動度が $1 \mathrm{~cm}^{2} / \mathrm{Vs}^{(5)}$, ルブレン単結晶を用いたもので移動度 $18 \mathrm{~cm}^{2} / \mathrm{Vs}^{(6)}$ が報告 されており，興味深い。現在，有機トランジスタ応用にか かる研究は，アクティブマトリクス駆動用の画素スイッチ に関するものが主流であり，フレキシブルシートディスプ

* (株) リコー先端研

干 224-0035 横浜市都筑区新栄町 16-1 RICOH Co. LTD.

1-1-1 Shinei, Tsuzuki, Yokohama 224-0035

** 千葉大学先進科学研究教育センター

干263-8522 千葉市稲毛区弥生町

1-33ChibaUniversity,

1-33 Yayoi-cho, Inage-ku, Chiba 263-8522

*** 千葉大学大学院工学研究科

干263-8522 千葉市稲毛区弥生町

1-33 Advanced Organic Device Project,

1-33 Yayoi-cho, Inage-ku, Chiba 263-8522
レイの実現に不可欠な有機トランジスタを用いた論理素子 やインバーター回路に関する研究は少ない(7) (10)。有機論理 素子の実現にあたっては, その基本構成である $\mathrm{n}$ チャネル トランジスタと $\mathrm{p}$ チャネルトランジスタを対称的に組み合 わせた CMOS (Complementary Metal Oxide Semiconductor）インバーターの実用的な実現が当面の課 題である。しかしながら，有機半導体材料の多くは $\mathrm{p}$ 型の 電気的性質を示し, $\mathrm{n}$ 型を示寸有機材料が希少であることか ら $\mathrm{n}$ 型有機トランジスタの実現の可能性は低い。良好な特 性を有する CMOS インバーターを得るには，比較的特性の 揃った $\mathrm{n}$ チャネル， p チャネルトランジスタを組み合わせ る必要がある。これまでに，われわれは，RF（Radio Frequency）スパッタ法により作製した酸化亜鉛（ $\mathrm{ZnO} ）$ 薄 膜に対する $\mathrm{X}$ 線回折法による $\mathrm{ZnO}$ 薄膜の配向性の評価と電 気的評価を行った結果により, $\mathrm{ZnO}$ トランジスタおよび tris (8-hydroxyquinolinolato) aluminum : (Alq $\left.{ }_{3}\right)$ を発光層に用 いた有機 LED (Light Emitting Diode) を作製し， ZnO 薄 膜は有機発光トランジスタとして使用可能であることを報 告した(11)(12)。また, 透明電極としても使用可能で, かつ, $\mathrm{n}$ 型のワイドギャップ半導体である $\mathrm{ZnO}$ 系材料を用いた $\mathrm{n}$ 型 
トランジスタ(13) (17)に着目して，有機トランジスタと組み 合わせた CMOS インバーターを提案している(18)。

本論文では，まず， $\mathrm{ZnO}$ 薄膜の電荷輸送特性の解析と評 価を行った結果を示す。つぎに， $\mathrm{ZnO}$ トランジスタを $\mathrm{n}$ チ ヤネル, ペンタセントランジスタを $\mathrm{p}$ チャネルとした構成

の CMOS インバーターの性能について報告する。

\section{2. $\mathrm{ZnO}$ 薄膜の成膜条件と電気的性質}

$\langle 2 \cdot 1\rangle \quad \mathrm{Glass} / \mathrm{ITO} / \mathrm{ZnO} / \mathrm{Al}$ 構造の電気的性質 良い CMOS インバーターを実現するためには，ペンタセン p チ ヤネルトランジスタに合うような $\mathrm{ZnO} \mathrm{n}$ チャネルトランジ スタを組み合わせる必要があり，作製条件を変えて，適合 するトランジスタを作ることが重要である。とくに，駆動 トランジスタである $\mathrm{ZnO}$ トランジスタの高性能化が必須で あり，低電圧動作で高速の $\mathrm{ZnO}$ トランジスタが実現できれ ば，低い閾電圧と高い利得の CMOS インバーターが得られ るはずである。ここで注目すべきことは，トランジスタ動 作時の $\mathrm{ZnO}$ 薄膜中への電荷注入と電荷移動であると考え た。 $\mathrm{ZnO}$ 薄膜の電気伝導を明らかにすることは $\mathrm{ZnO}$ トラン ジスタの高性能化のためのキーとなる課題である。とくに, $\lceil\mathrm{ZnO}$ 薄膜への電荷注入と電極界面の影響」に着目して, $\mathrm{ZnO}$ 薄膜の電気的性質を調べた。図 1 は電気特性評価用に 作製した $\mathrm{Sn}$ ドープ $\mathrm{In}_{2} \mathrm{O}_{3}$ （インジウム錫酸化物（ITO）） $\mathrm{ZnO} / \mathrm{Al}$ サンドイッチ構造である。作製手順は，ITO 膜厚 $110 \mathrm{~nm}$ 付ガラス基板 (CORNING 社製 $1737 \mathrm{~F}$ 厚さ $1.1 \mathrm{~mm}$ ) 上に ITO 電極パターンをリソグラフィー法により作製後, $\mathrm{RF}$ スパッタ法により $\mathrm{ZnO}$ 薄膜を成膜した。陽極は真空蒸 着法によるアルミニウム $(\mathrm{Al})$ を用いた。 $\mathrm{Al}$ 電極は円形で あり，有効素子面積は $1.75 \mathrm{~mm}^{2}$ である。 $\mathrm{Al}$ 蒸着時の基板 温度は，室温で行った。 $\mathrm{ZnO}$ 薄膜は，2 種類のガス流量条 件をパラメータとして成膜した。スパッタ装置チャンバー 内の成膜時の圧力 $0.8 \mathrm{~Pa}, \mathrm{RF}$ パワー密度 $1.65 \mathrm{~W} / \mathrm{cm}^{2}$ は, 共通成膜条件とした。評価用試料作製後，測定はす心゙て真 空中，暗状態にて行った。図 2 は，作製した $\mathrm{ZnO}$ 薄膜の電 流一電圧特性 $(I-V$ 特性 $)$ である。図 2 中の(a)はアルゴン

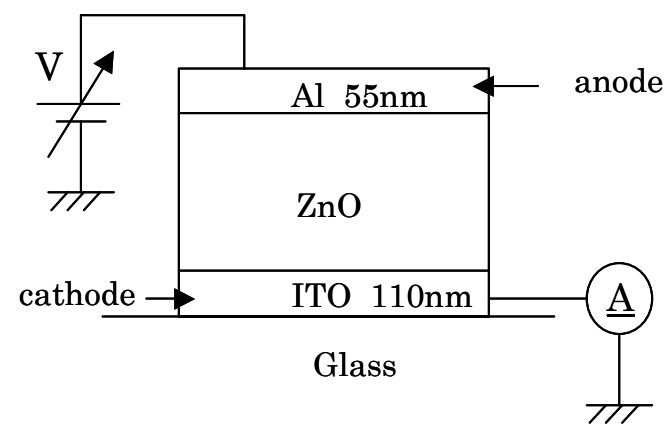

図 $1 \mathrm{ZnO}$ 薄膜評価のための $\mathrm{ITO}$ と $\mathrm{Al}$ 電極で挟んだ構造の 評価用素子断面図

Fig. 1. Sample structure sandwiched by ITO electrode and $\mathrm{Al}$ electrode for evaluate $\mathrm{ZnO}$ thin films.
(Ar) ガス流量 $10 \mathrm{sccm},(\mathrm{b})$ は $\mathrm{Ar}$ ガス流量 $5 \mathrm{sccm}$, 酸素 $\left(\mathrm{O}_{2}\right)$ ガス流量 $5 \mathrm{sccm}$ で成膜した $\mathrm{ZnO}$ 薄膜の電気特性である。

Ar ガス流量 $10 \mathrm{sccm}$ で成膜した試料はオーミック接触であ った。一方, $\mathrm{Ar}$ ガス流量 $5 \mathrm{sccm}, \mathrm{O}_{2}$ ガス流量 $5 \mathrm{sccm}$ で成 膜した試料は, 立ち上がり電圧約 $1.2 \mathrm{~V}$ のダイオード特性を 示した。

$\langle 2 \cdot 2\rangle \quad \mathrm{ZnO}$ 薄膜の電荷輸送機構 電極 $/ \mathrm{ZnO}$ 薄膜界 面の電荷注入は, 電極のフェルミ準位から $\mathrm{ZnO}$ の伝導帯の 位置までのエネルギー差に対応する電荷注入障壁の高さに よって左右されると考えられる。また, 界面トラップの電 荷移動に影響する界面準位については，界面トラップ準位

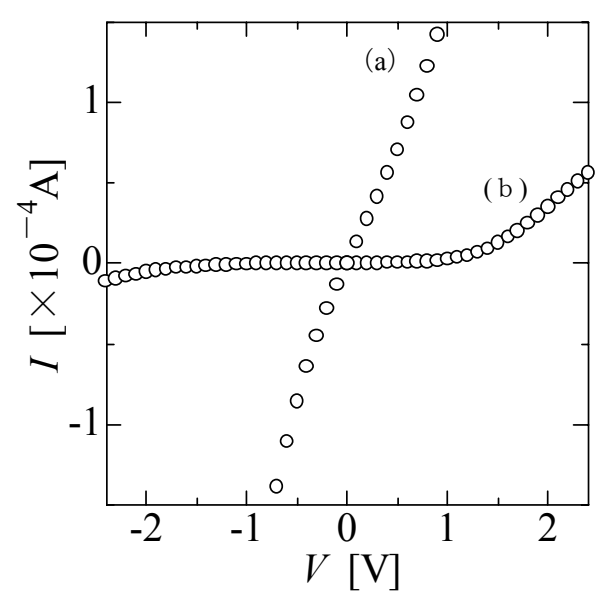

図 $2 \mathrm{ZnO}$ 薄膜の電流一電圧特性（a）アルゴン $10 \mathrm{sccm}$

(b) アルゴン $5 \mathrm{sccm}$ ，酸素 $5 \mathrm{sccm}$

Fig. 2. $I-V$ characteristics of $\mathrm{ZnO}$ thin film. (a) Deposition condition of Ar $10 \mathrm{sccm}$ (b) Ar 5 sccm and $\mathrm{O}_{2} 5 \mathrm{sccm}$.

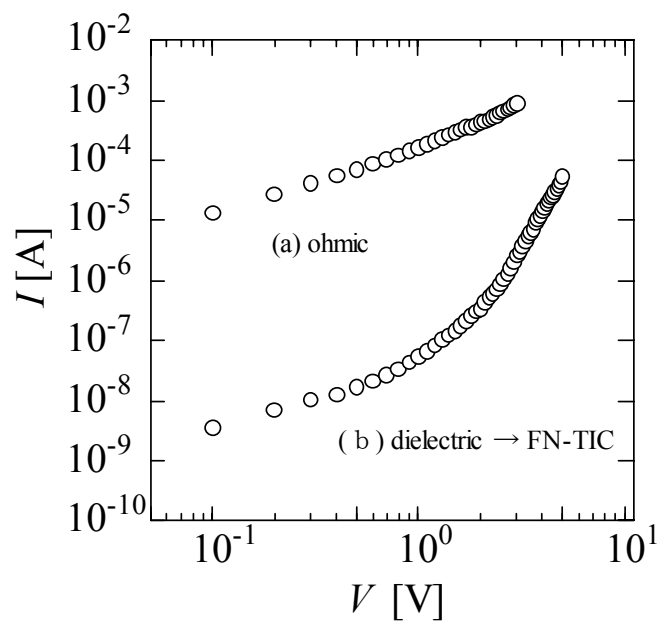

図 $3 \mathrm{ZnO}$ 薄膜の電流一電圧特性プロット

Fig. 3. Current vs bias voltage plots of $\mathrm{ZnO}$ thin films. 


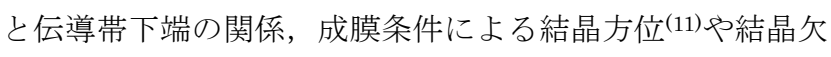
陥に加えて，表面処理による污れなどの影響による仕事関 数の変化によって生じると考えられる。図 2 に示した $I-V$ 特性データを両対数プロットして, 電荷注入機構について 検討した。図 3(a)は $\mathrm{Ar}$ ガス流量 $10 \mathrm{sccm}$ で成膜した $\mathrm{ZnO}$ 薄膜の $I-V$ 特性である。一方, 図 $3(\mathrm{~b})$ に示す $\mathrm{Ar}$ ガス流量 $5 \mathrm{sccm}, \mathrm{O}_{2}$ ガス流量 $5 \mathrm{sccm}$ で成膜した $\mathrm{ZnO}$ 薄膜の電流の 電圧依存性おいては, $2 \sim 3 \mathrm{~V}$ 付近で変曲が見られる。 $\mathrm{ZnO}$ 薄膜において, 以上のような電気伝導性の違いが生じる原 因は, $\mathrm{ZnO}$ 薄膜の $\mathrm{C}$ 軸が優性配向であるか $\mathrm{C}$ 軸以外の優性 配向であるかによって，電気的な性質を制御できることに よっている(11)。電気特性がどのようになるのかは, 膜内一 の電荷注入のされ方と膜内での電荷輸送のされ方との関連 性が深い。一般的に, 室温付近においては, 比較的厚い膜 厚領域ではバルク制限の電気伝導が支配的であり, 薄い膜 厚領域では電極 $/ \mathrm{ZnO}$ 薄膜界面の電気伝導が支配的である と考えられる。このことはわれわれのほかの実験, ペンタ セン薄膜を用いた縦型トランジスタの電気伝導の検討によ り，すでに報告しており，ITO／ペンタセン界面に極薄膜 $\mathrm{CuPc}$ を挿入することにより Fowler-Nordheim トンネリン グ理論に従う注入電流が増大する結果が得られてい $ろ^{(19) \sim(21)}$ 。本実験の図 5(b)においても同様に, $\mathrm{ZnO}$ 薄膜の 優先配向性に起因する電極 $/ \mathrm{ZnO}$ 薄膜界面現象により印加 電圧を大きくするにつれて Fowler-Nordheim トンネリング 理論に従う電荷注入に変化していることが予想できる。こ れらのことから, $\mathrm{ZnO}$ 薄膜トランジスタにおいては, 電極 からの電荷注入がトランジスタ動作の良否を決定する重要 な要素であると考えている。

\section{3. トランジスタの作製と動作特性}

$\mathrm{ZnO}$ 薄膜の成膜条件と電気的性質の検討結果に基づい て，トランジスタを作製した。本実験に用いたトランジス タは, ソース電極からドレイン電極へ向かうキャリアの流

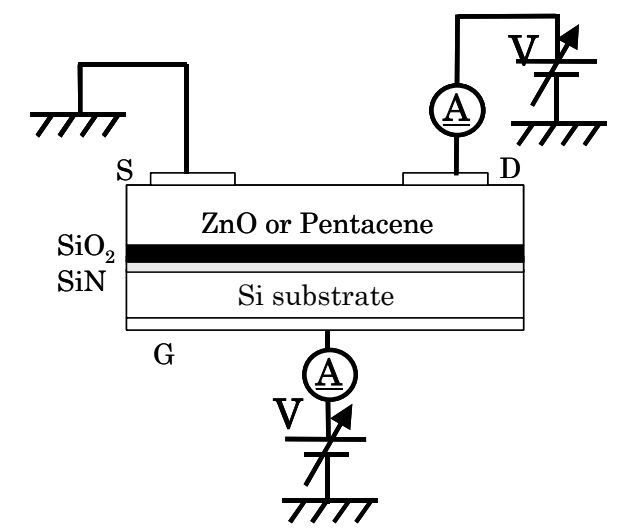

図 $4 \mathrm{Si}$ 基板上に作製した $\mathrm{ZnO}$ トランジスタとペンタセン トランジスタの素子構造

Fig. 4. Schematic diagram of $\mathrm{ZnO}$ and pentacene transistor on Si substrate.
れを実質的にゲート電極に印加する電圧で制御する電界効 果トランジスタである。図 4 は, $\mathrm{ZnO}$ トランジスタとペン タセントランジスタの素子断面構造と測定回路系である。 低抵抗 $\mathrm{p}$ 型シリコン（Si）基板（100）表面に熱 CVD (Chemical Vapor Deposition) 法により $150 \mathrm{~nm}$ の窒化ケイ 素 $(\mathrm{SiN})$ 薄膜を絶縁層として形成した後に, $400 \mathrm{~nm}$ の二 酸化ケイ素 $\left(\mathrm{SiO}_{2}\right)$ 薄膜を形成し, 二層の絶縁層構造にして ある。これにより, $\mathrm{RF}$ スパッタ法による $\mathrm{ZnO}$ 薄膜成膜時 に生じる絶縁層に対するダメージの軽減を図り, トランジ スタを作製した際にゲートリーク電流を抑制する効果を期 待している。また, 硬くて脆いが緻密な性質の $\mathrm{SiN}$ 薄膜を 配置し, その上に $\mathrm{SiO}_{2}$ 薄膜を配置することによって, $\mathrm{SiO}_{2}$ 単層膜による絶縁膜よりも薄く形成できる利点がある。さ らに, SiN 単層膜によるよりも薄膜中のクラック発生を防 止できる利点がある。低抵抗 $\mathrm{p}$ 型 $\mathrm{Si}$ 基板の裏面に, 真空蒸 着法により $\mathrm{Al}$ 電極を形成した。測定はすべて真空中, 暗状 態で行った。

〈3.1〉 ZnO トランジスタの作製方法 $\mathrm{ZnO}$ トランジ スタは, 図 4 に示す構造で作製した。各層の膜厚は, $\mathrm{Al}$ ゲ 一ト電極 : $100 \mathrm{~nm}, \mathrm{Al}$ ソース・ドレイン電極 : $150 \mathrm{~nm}$ に 設定した。チャネル長 : $20 \mu \mathrm{m}$, チャネル幅 : $3 \mathrm{~mm}$ (櫛 型電極 $1.5 \mathrm{~mm} \times 2$ ペア）である。 $\mathrm{ZnO}$ 薄膜は, 前述の $\mathrm{SiN}$ $/ \mathrm{SiO}_{2}$ 絶縁膜付 $\mathrm{Si}$ 基板上に $\mathrm{RF}$ スパッタ法により $70 \mathrm{~nm}$ の 厚さで成膜した。 $\mathrm{ZnO}$ 薄膜の成膜条件は, スパッタ装置チ ヤンバー内の成膜時の圧力 $0.8 \mathrm{~Pa}, \mathrm{RF}$ パワー密度 1.65 $\mathrm{W} / \mathrm{cm}^{2}, \mathrm{Ar}$ 流量 $10 \mathrm{sccm}$ で成膜した。成膜は ANELVA 社 製スパッタ装置 (L-332S) を使用した。ZnO ターゲットは, 真空治金(株)製, $\phi 75 \cdot 5 \mathrm{~mm}$ 厚, 純度 $99.9 \%$ を使用した。 $\mathrm{Al}$ ソース・ドレイン電極はメタルシャドウマスクを用い, 真空蒸着法により形成した。

〈3·2〉 ZnO トランジスタの動作特性 図 5 は, 作製 した ZnO トランジスタの動作特性である。図 5(a)に示すよ うに, ソース・ドレイン電圧 $\left(V_{D S}\right)$ は $0 \mathrm{~V}$ から連続的に 30 $\mathrm{V}$ まで変化させ, ゲート電圧 $\left(V_{G}\right)$ は, $-20 \mathrm{~V}$ から+100 V まで $20 \mathrm{~V}$ ステップで変化させた。ドレイン電流 $\left(I_{D S}\right)$ は, $10^{-4} \mathrm{~A}$ オーダーが得られ, 出力特性において明瞭な変調特 性が見られた。トランジスタの静特性の直線領域から見積 もった電界効果移動度 $(\mu)$ は $2.1 \times 10^{-3} \mathrm{~cm}^{2} / \mathrm{Vs}$ が得られ た。図 $5(\mathrm{~b})$ は同一の素子の $\log \left(I_{D S}\right)$ と $I_{D S^{1 / 2}}$ の $V_{G}$ 依存性 を示す伝達特性である。伝達特性から, 才フ電流〜 $10^{-9} \mathrm{~A}$, オン・オフ比 $10^{5}$, 閾值電圧 (Vth) 約 $20 \mathrm{~V}$ が得られた。 ゲート電圧 $20 \mathrm{~V}$ 時の電流值から見積もった電気伝導度 （ o ）は， $1.3 \times 10^{-5} \mathrm{~S} / \mathrm{cm}$ が得られ，これから求めたキャリ ア密度は $3.9 \times 10^{16} \mathrm{~cm}^{-3}$ であった。一方, 図 $2(\mathrm{a})$ アルゴン $10 \mathrm{sccm}$ のスパッタ成膜条件で成膜した $\mathrm{ZnO}$ 薄膜の電流一 電圧特性から見積もった $\sigma$ は, $1.9 \times 10^{-7} \mathrm{~S} / \mathrm{cm}$ が得られ, キャリア密度は, $6.0 \times 10^{14} \mathrm{~cm}^{-3}$ であった。 $\mathrm{ZnO}$ トランジ スタの動作特性から見積もったキャリア密度は, 2 端子構造 $\mathrm{ZnO}$ 薄膜のそれよりも二桁程度大きな值が得られた。これ の原因は, トランジスタでは, 電荷はゲート電圧によりト 

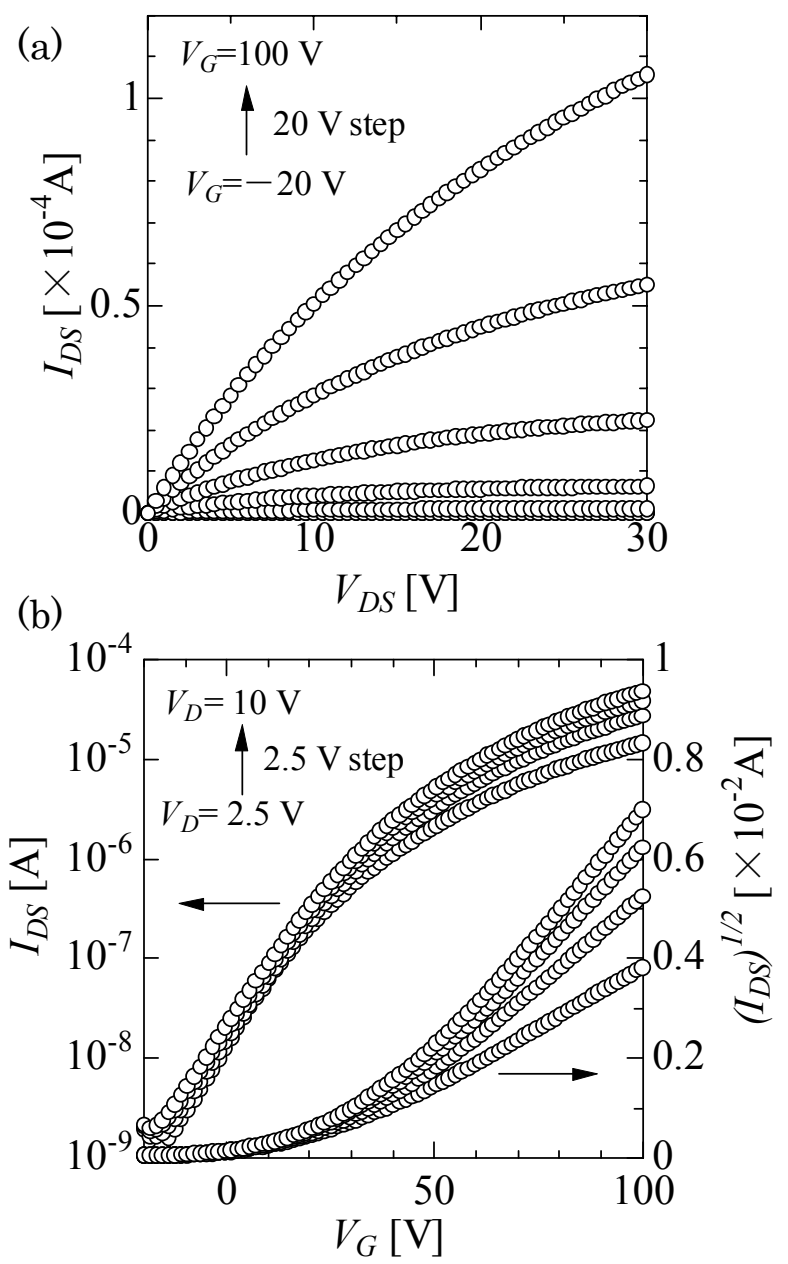

図 $5 \mathrm{ZnO}$ TFT $の$ 動作特性（a）静特性 （b）伝達特性

Fig. 5. Characteristics of $\mathrm{ZnO}$ transistor. (a) Static characteristics. (b) Transfer characteristics.

ランジスタのチャネル領域に誘起されているのに対して，2 端子構造においては, 電荷はむしろ $\mathrm{ZnO}$ 薄膜中或いは $\mathrm{ZnO} /$ 電極界面にトラップされていることにより実効的なキャリ ア密度の差が観察されているものと考えている。

〈3.3〉 ペンタセントランジスタの作製方法 ペンタ セントランジスタは, 図 4 に示寸構造で作製した。各層の 膜厚および寸法は, $\mathrm{Al}$ ゲート電極 : $100 \mathrm{~nm}, \mathrm{Au}$ ソース, ドレイン電極 : $150 \mathrm{~nm}$ に設定した。チャネル長 : $100 \mu \mathrm{m}$, チャネル幅 : $30 \mathrm{~mm}$ （櫛型電極 : $5 \mathrm{~mm} \times 6$ ペア）である。 ペンタセン薄膜は真空蒸着法により成膜した。膜厚は 70 $\mathrm{nm}$ である。成膜条件は, 真空蒸着装置チャンバー内の成膜 時の圧力 $2 \times 10^{-4} \mathrm{~Pa}$, 蒸着源の温度 $200{ }^{\circ} \mathrm{C}$, 成膜レート $0.1 \mathrm{~nm} / \mathrm{s}$ である。ソース・ドレイン電極蒸着時の基板温度 は室温に設定した。

〈3.4〉 ペンタセントランジスタの動作特性 図 6 は, ペンタセントランジスタの動作特性である。図 6(a)に示す ように, $V_{D S}$ は $0 \mathrm{~V}$ から連続的に $-40 \mathrm{~V}$ まで変化させ， $V_{G}$ は+ $20 \mathrm{~V}$ からー $40 \mathrm{~V}$ まで $10 \mathrm{~V}$ ステップで変化させた。IDS
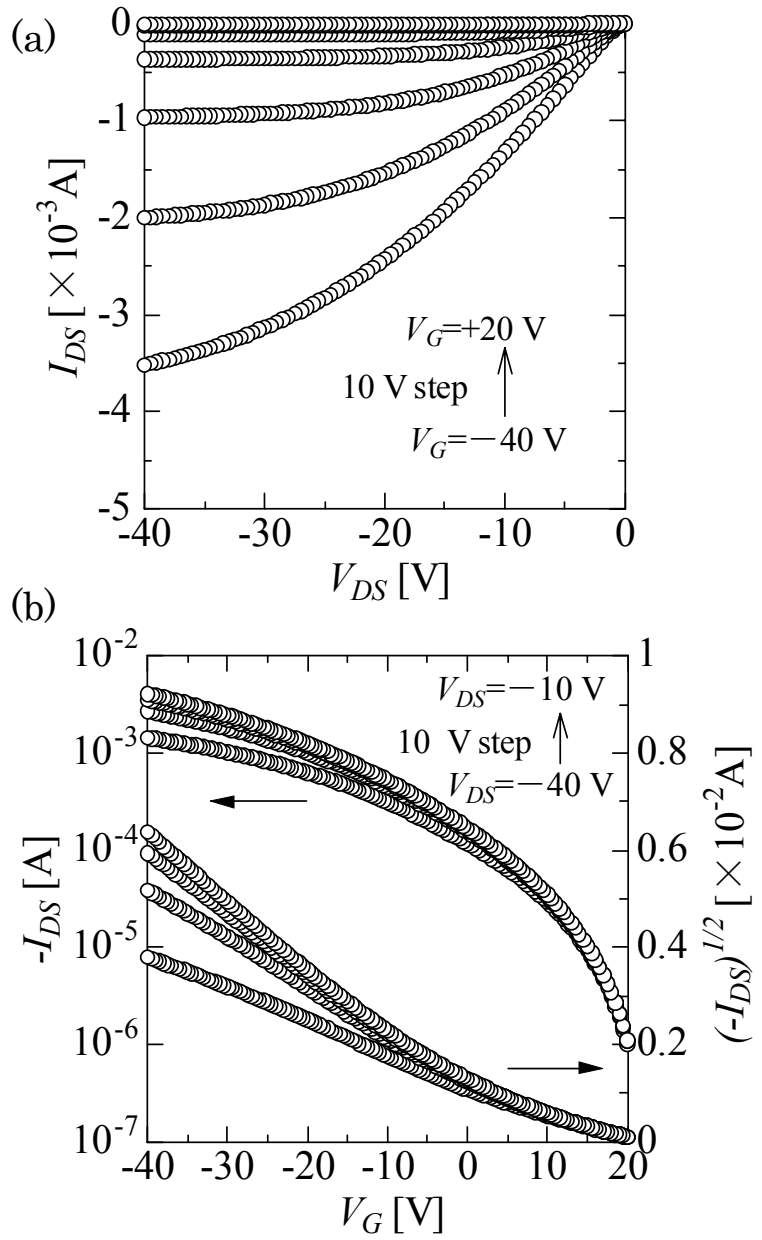

図 6 ペンタセン TFT の動作特性（a）静特性

（b）伝達特性

Fig. 6. Characteristics of pentacene transistor. (a) Static characteristics. (b) Transfer characteristics.

は, $10^{-3} \mathrm{~A}$ オーダーの電流值が得られ, 明瞭な変調特性が 見られた。図 6(b)は, 同一の素子の $\log \left(I_{D S}\right)$ と $I_{D S^{1 / 2}}$ の $V_{G}$ 依存性を示寸伝達特性である。伝達特性から, オフ電流〜 $10^{-6} \mathrm{~A}$ ，オン・オフ比 $10^{3}, V t h$ は約 $10 \mathrm{~V}$ が得られた。 $\mu$ は, $3.2 \times 10^{-2} \mathrm{~cm}^{2} / \mathrm{Vs}$ であった。ペンタセントランジス タのゲート電圧 $10 \mathrm{~V}$ 時の動作特性の直線領域から見積もつ た $\sigma$ は， $4.4 \times 10^{-4} \mathrm{~S} / \mathrm{cm}$ が得られた。 $\sigma$ から求めたキャリ ア密度は, $8.7 \times 10^{16} \mathrm{~cm}^{-3}$ であった。図 7 は, 図 1 に示し た構造で, ペンタセン薄膜を ITO 電極とAu 電極で挟んだ 構成で作製したペンタセン薄膜の $I-V$ 特性である。ペンタ セン薄膜の厚さは, $200 \mathrm{~nm}$ である。この $I-V$ 特性から見 積もった $\sigma$ は, $1.6 \times 10^{-7} \mathrm{~S} / \mathrm{cm}$ が得られ, キャリア密度は, $3.2 \times 10^{14} \mathrm{~cm}^{-3}$ であった。ペンタセントランジスタの動作 特性から見積もったキャリア密度は, 2 端子構造の $I-V$ 特 性から見積もったよりも二桁程度大きかった。これの原因 も, $\mathrm{ZnO}$ 薄膜のキャリア密度を調べた結果と同様に, 電荷 輸送に寄与寸る実効的なキャリア密度に差が生じているも のと考えている。このような現象は, 長い時定数をもつ卜 


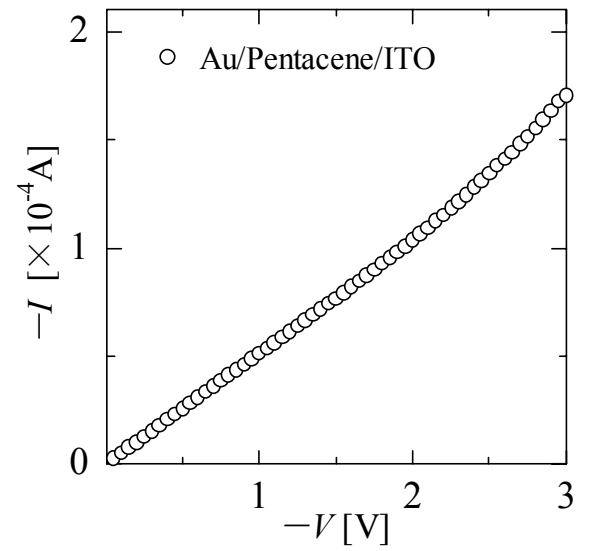

図 7 Pentacene 薄膜の電流一電圧特性

Fig. 7. $I$ - $V$ characteristics of pentacene thin film.

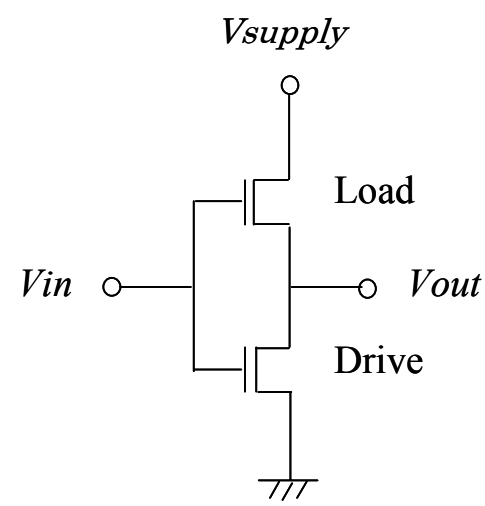

図 8 CMOS インバーター回路

Fig. 8. CMOS inverter circuit.

ラップや空乏層の電気的性質や障壁の高さに関係している と推察されるので, 新しい材料である酸化物半導体や有機 半導体の特性を知る上で最も基本的で重要な手法である各 バイアス電圧下における接合容量の測定などによって，理 論的に扱う必要がある。

〈3.5〉CMOSインバーター 図8は, CMOSインバ ーターの回路図である。CMOS インバーターは， $\mathrm{n}$ チャネ ル $\mathrm{ZnO}$ トランジスタ駆動素子と $\mathrm{p}$ チャネルペンタセントラ ンジスタ負荷素子を独立に作製し，回路的に接続して組み 合わせた。図 9 は CMOS インバーターの電圧伝達特性であ る。供給電圧 $\left(V_{\text {supply }}\right)$ は, $+10 \mathrm{~V}$ および+20 Vで印加し た。低い入力電圧 $\left(V_{i n}\right)$ 領域では, ペンタセントランジス タがオン状態になり $\mathrm{ZnO}$ トランジスタがオフ状態になるの で供給電圧が出力 $\left(V_{\text {out }}\right)$ されている。一方，高い $V_{\text {in }}$ 領域 では， ZnO トランジスタがオン状態になりペンタセントラ ンジスタがオフ状態になるので $0 \mathrm{~V}$ が出力されている。両 方のトランジスタによって決定される CMOSインバーター の閾電圧は, $60 \mathrm{~V}$ から $70 \mathrm{~V}$ 近傍であった。電圧利得（Gain= $\left.\Delta V_{\text {out }} / \Delta V_{\text {in }}\right)$ は，10-12 程度が得られた。

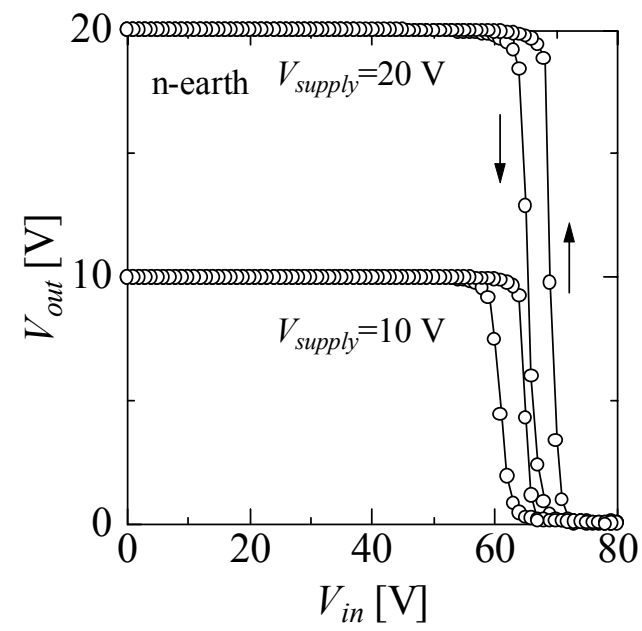

図 9 ペンタセントランジスタと $\mathrm{ZnO}$ トランジスタを組み

合わせた CMOS インバーターの伝達特性

Fig. 9. Voltage transfer characteristics of CMOS inverter employing pentacene and $\mathrm{ZnO}$ transistor.

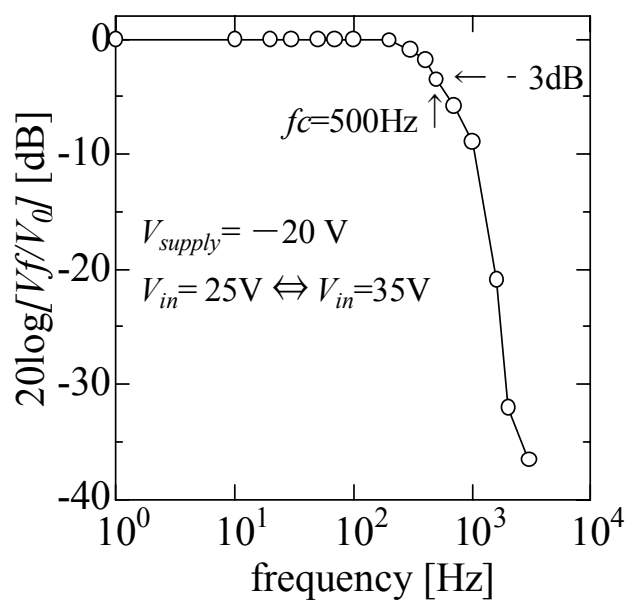

図 10 ペンタセントランジスタと $\mathrm{ZnO}$ トランジスタを組 み合わせた CMOS インバーターの周波数特性

Fig. 10. Frequency response of CMOS inverter employing pentacene and $\mathrm{ZnO}$ transistor.

つぎに，ゲートに正弦波交流電圧を印加して，CMOS イ ンバーターの動特性（周波数特性）を測定した。図 10 に示 す。測定条件は, $V_{\text {supply }}=20 \mathrm{~V}, V_{\text {in }}$ の幅は $25 \mathrm{~V} \sim 35 \mathrm{~V}$ で ある。特性が $3 \mathrm{~dB}$ 低下となる周波数を遮断周波数 $\left(f_{c}\right)$ と定 義すると， $f_{c}=500 \mathrm{~Hz}$ となった。

\section{4. まとめ}

$\mathrm{RF}$ スパッタ法による $\mathrm{ZnO}$ 薄膜を用いた $\mathrm{n}$ チャネル $\mathrm{ZnO}$ トランジスタと真空蒸着法による $\mathrm{p}$ チャネルペンタセント ランジスタを作製し，無機・有機トランジスタの組み合わ せによる CMOS インバーターを作製した。電極 $/ \mathrm{ZnO}$ 薄膜 界面の基本的な電荷輸送機構について調べた結果, $\mathrm{ZnO}$ 薄 
膜を用いたトランジスタは電極からの電荷注入が重要な役 割を果たしていることがわかった。 $\mathrm{ZnO}$ 薄膜を用いたトラ ンジスタは，フレキシブルシートディスプレイのキーとな る構成要素として期待できる。今後は, 熱刺激電流（TSC： Thermally Stimulated Current) 測定法によるトラップ準 位と空間電荷の測定 ${ }^{(22)}, C-V$ 測定や電流の温度依存性によ る電極界面の電荷注入障壁や $\mathrm{ZnO}$ 薄膜の結晶格子構造と電 気的性質の関係を調べることにより，トランジスタの更な る高性能化が期待できると考えている。

\section{謝 辞}

本研究の一部は，科学研究費補助金（基盤研究 $\mathrm{B}$ 課題番 号 19360155）によって行われた。

(平成 19 年 5 月 31 日受付, 平成 19 年 8 月 21 日再受付)

\section{文献}

(1) C. D. Sheraw, L. Zhou, J. R. Huang, D. J. Gundlach, T. N. Jackson, M. G. Kane, I. G. Hill, M. S. Hammond, J. Campi, B. K. Greenning, J. Frank, and J. West : "Organic thin-film transistor-driven polymer-dispersed liquid crystal display on flexible polymeric substrate", Appl. Phys. Lett., Vol.80, No.6, pp.1088 (2002)

(2) Z. T. Zhu, J. T. Mason, R. Dieckmann, and G. G. Malliaras : "Humidity sensors based on pentacene thin-film transistors", Appl. Phys. Lett., Vol.81, pp.4643-4645 (2002)

(3) B. K. Crone, A. Dodabalapur, R. Sarpeshkar, A. Gelperin, H. E. Katz, and Z. Bao : "Organic oscillator and adaptive amplifier circuits for chemical vapor sensing", J. Appl. Phys., Vol.91, No.12, pp.10140 (2002)

(4) P. F. Baude, D. A. Ender, M. A. Haase, T. W. Kelly, D. V. Muyres, and S. D. Theiss : "Pentacene-based radio-frequency identification circuitry", Appl. Phys. Lett., Vol.82, No.22, pp.3964-3966 (2003)

(5) Y. Kato, S. Iba, R. Teramoto, T. Sekitani, H. Kawaguchi, T. Someya, H. Kawaguchi, and T. Sakurai : "High mobility of pentacene field-effect transistors with polyimide gate dielectric layers", Applied Phys. Let., Vol.84, No.19, pp.3789-3791 (2004)

(6) J. Takeya, M. Yamagishi, Y. Tominari, R. Hirahara, Y. Nakazawa, T. Nishikawa, T. Shimoda, and S. Ogawa : "Very high-mobility organic single-crystal transistors with in-crystal conduction channels", Appl. Phys. Let., Vol.90, pp.102120-1-102120-3 (2007)

(7) A. Dodabalapur, J. Baumbach, K. Baldwin, and H. E. Katz "Hybrid organic/inorganic complementary circuits", Appl. Phys. Lett., Vol.68, No.16, pp.2246-2248 (1996)

(8) A. Dodabalapur, J. Laquindanum H. E. Katz, and Z. Bao : "Complementary circuits with organic transistors", Appl. Phys. Lett., Vol.69, No.27, pp.4227-4229 (1996)

(9) H. Klark, D. J. Gundlach, and T. N. Jackson : "Fast Organic Thin-Film Transistor Circuits", IEEE Electron Device Lett., Vol.20, No.6, pp.289-291 (1999)

(10) Y. Inoue, Y. Sakamato, T. Suzuki, M. Kobayashi, Y. Gao, and S. Tokito : "Organic Thin-Film Transistors with High Electron Mobility Based on Perfluoropentacene”, Jpn. J. Appl. Phys., Vol.44, No.6, pp.3663-3668 (2005)

(11) H. Iechi, K. Okawara, M. Sakai, M. Nakamura, and K. Kudo : "Vertical Type Organic Devices using Thin Film ZnO Transparent Electrode", IEEJ Trans. EIS, Vol.124, No.6, pp.1207-1212 (2004-6) (in Japanese)

家地洋之 ・大河原健・酒井正俊・中村雅一・工藤一浩：「酸化亜鉛透 明電極を用いた縦型有機デバイス」, 電学論 C, 124, 6, pp.1207-1212 (2004-6)

(12) H. Yamauchi, M. Iizuka, and K. Kudo : "Fabrication of Vertical Organic Light-Emitting Transistor Using ZnO Thin Film”, Jpn.
J. Appl. Phys., Vol.46, No.4B, pp.2678-2682 (2007)

(13) Y. Ohya, T. Niwa, T. Ban, and Y. Takahashi : "Thin Film Transistor of ZnO Fabricated by Chemical Solution Deposition", Jpn. J. Appl. Phys., Vol.40, No.1, pp.297-298 (2001)

(14) K. Nomura, H. Ohta, K. Ueda, T. Kamiya, M. Hirano, and H. Hosono : "Thin Film Transistor Fabricated in Single-Crystalline Transparent Oxide Semiconductor", Science, Vol.300, pp.1269-1272 (2003)

(15) R. L. Hoffman, B. J. Norris, and J. F. Wager : "ZnO based transparent thin-film transistors", Appl. Phys. Lett., Vol.82, pp.733-735 (2003)

(16) P. F. Carcia, R. S. McLean, M. H. Reilly, and G. Nunes : "Transparent $\mathrm{ZnO}$ thin-film transistor fabricated by $\mathrm{RF}$ magnetron sputtering", Appl. Phys. Lett., Vol.82, pp.1117-1119 (2003)

(17) J. Nishi, F. M. Hossain, S. Takagi, T. Aita, K. Saikusa, Y. Ohmaki, I. Ohkubo, S. Nishimoto, A. Ohtomo, T. Fukumura, F. Matsukusa, Y. Ohno, H. Koinuma, H. Ohno, and M. Kawasaki : "High Mobility Thin Film Transistor with Transparent ZnO Channels", Jpn. J. Appl. Phys., Vol.42, pp.347-349 (2003)

(18) H. Iechi, Y. Watanabe, and K. Kudo : "Inverter Circuits using Pentacene and ZnO Transistors", Jpn. J. Appl. Phys., Vol.48, No.4B, pp.2645-2649 (2007)

(19) Y. Watanabe, H. Iechi, and K. Kudo : "Improvement in On/Off Ratio of Pentacene Static Induction Transistors with Ultrathin CuPc Layer", Jpn. J. Appl. Phys., Vol.45, No.4B, pp.3698-3703 (2006)

(20) Y. Watanabe, H. Iechi, and K. Kudo : "Effect of ITO Surface Condition on the Characteristics of Organic Static Induction Transistors Based on Pentacene Films", Transactions of the Materials Research Society of Japan., Vol.31, No.3, pp.593-596 (2006)

(21) Y. Watanabe, H. Iechi, and K. Kudo : "Improvement in On/Off Ratio of Pentacene Static Induction Transistors by Controlling Hole Injection Barrier", Jpn. J. Appl. Phys., Vol.46, No.4B, pp.2717-2721 (2006)

(22) S. Kuniyoshi, S. Naruge, M. Iizuka, M. Nakamura, K. Kudo, and K. Tanaka : "Thermally stimulated current of pentacene Schottky diode", Synthetic Metals, Vol.137, pp.895-896 (2003)

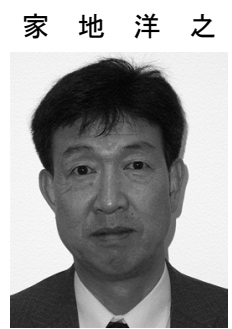

（正員） 1954 年 3 月 6 日生。 1977 年 3 月防 衛大学理工系応用化学教室卒業。1984 年（株） リコー入社, 化合物半導体薄膜形成と評価に関 する研究に従事。現在, 千葉大学大学院工学研 究科博士後期課程。有機半導体薄膜形成と素子 作製および評価に関する研究に従事。応用物理 学会会員。

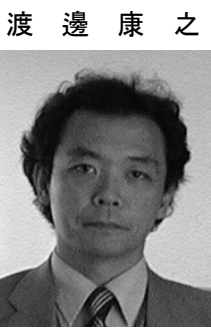

（非会員） 1970 年 5 月 18 日生。 1998 年 3 月 東京理科大学大学院工学研究科電気工学専攻 博士課程単位取得退学。現在, 千葉大学先進科 学研究教育センター特任教員。化合物半導体薄 膜及び有機半導体薄膜形成と評価に関する研 究に従事。応用物理学会会員。博士 (工学)。 


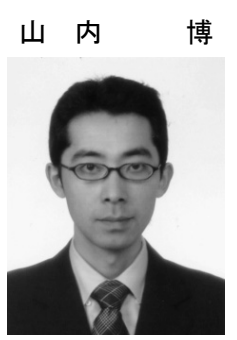

工 藤 一 浩 (正員) 1954 年 8 月 15 日生。 1982 年 3 月東 山形大学工学部機械システム工学科卒業。現 在, 千葉大学工学部技術職員。有機半導体薄膜 形成と評価に関する研究に従事。応用物理学会 会員。

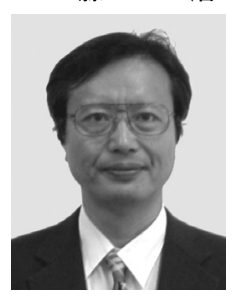

京工業大学理工学研究科博士課程修了。松下電

器産業（株）入社。1987 年千葉大学工学部助 教授, 1998 年同教授。有機半導体薄膜及び化 合物半導体薄膜の形成と評価に関する研究に 従事。応用物理学会会員, 電子情報通信学会会

員, 高分子学会会員。工学博士。 